\title{
TESTIMONIES OF VICTIMS OF HUMAN RIGHTS VIOLATIONS AS PRIMARY SOURCES IN THE REPORTS BY UNITED NATIONS BODIES
}

\author{
ELOÍSA GONZÁLEZ HIDALGO ${ }^{1}$
}

\begin{abstract}
Victims of crimes, victims of abuse of power and victims of gross and systematic human rights violations have had little relevance to international law. However, since 1985, international human rights law has taken an interest in them and has created four instruments, which establish different notions of victim, as well as a catalogue of rights. Since then, victims have become increasingly prominent in processes involved in seeking justice, truth and reparation. Recently, victim's testimonies are used as one of the indicators, although not the only one, for measuring compliance and protection of human rights rules in the United Nations system.
\end{abstract}

Keywords: International law, human rights, testimonies, victims, data generation.

Contents: InTRODUCTION; I. UnITED NATIONS STANDARDS RELATING TO VICTIMS. TYPOLOGY; II. VICTIMS' RIGHTS WITHIN THE UNIVERSAL SYSTEM; III. GENERATION OF DATA AND INFORMATION BASED ON VICTIMS' TESTIMONIES; III.1 Events-based data: collecting testimonies; CONCLUSIONS; REFERENCES.

\section{INTRODUCTION}

According to Drapin (Drapin, 1974) as the State gradually took responsibility for the administration of justice, any individual who broke the law became the main character of judicial strata, leaving the victims in the background and even consigned to oblivion.

Since states had the upper hand in this regard, international law paid little attention to the victims. From the end of the Second World War, victims of human rights crimes and violations gradually started to be taken notice of through the development of international human rights law, international criminal law and international humanitarian law.

While it is true that these three branches of international law have focused on sanctioning or punishing the perpetrators of crimes and violations ${ }^{2}$, from the second half

\footnotetext{
1 Former postdoctoral fellow at the Pedro Arrupe Human Rights Institute, University of Deusto, Spain (eloisagh@deusto.es).

${ }^{2}$ International human rights law deals with human rights violations committed by states, while international criminal law is responsible for non-state authors and international humanitarian law seeks to condemn both state and individual perpetrators. For more information about this issue, see: Clapham, A. (2006) Human Rights of Non State Actors, Oxford: Oxford University Press. Singer, P. W. (2005) 'Outsourcing War', Foreign Affairs, 84 (2), p. 119-132; Hoss, Villalpando and Sivakumaran (2012) 'Nicaragua: 25 Years Later ', Leiden Journal of International Law, 25 (1), p. 131-133.
} 
of the 20th century victims have slowly seen their importance recognised in the processes seeking justice, truth and reparation within international human rights law.

This is mainly due to three reasons. The first reason is that states have been constituted into social and democratic States of Law where the criminal process is conceived as an instrument for safeguarding the recognised system of fundamental values, rights and freedoms. This process is intended to guarantee the rights of both people accused of committing a crime, and of the victims and of the rest of the population (Sanz Hermida, 2009, p. 25). For victims of human rights and humanitarian law violations, this means that they must be safeguarded and their rights must be protected. The second reason is that it is necessary to meet the demands for justice, truth, and compensation, as well as reparation to the victims for the psychological, physical, social, political, and other consequences that have been caused by the serious violations committed during and after armed conflicts. Some of these conflicts have been ethnic or religious, or been carried out by totalitarian regimes, etc. And, the third reason is the emergence of a new legal discipline, namely victimology, which has given the victims of crime an increasingly active role both in criminal law and in international human rights law. Victimology studies the victim from several perspectives: (a) bio-psycho-social; (b) criminological, and (c) legal, that is, the victim's relationship with substantive law and with the criminal process, which is directly linked to the issue of reparation and justice. ${ }^{3}$ This has resulted in the construction of a system of protection and victim's rights that states are obliged to comply with; otherwise they must repair the harm caused.

Similarly, channels have been created in the universal system for testimonies to be treated as sources of information in the collection of data on the human rights situation in UN Member States. They are to be included in the indicators to measure compliance with and protection of human rights standards.

The aim of this paper is to visualize the delayed attention that international law has given to the victims, the victim-related instruments established under international human rights law, and the inclusion of testimonies within the indicators for monitoring and assessing compliance with human rights in the universal system. It is important to mention that this paper does not elaborate an in-depth analysis on this subject but it is about a general global situation. However, an in-depth study on the importance of the testimonies of victims of human rights violations as primary sources in the reports by United Nations agencies is urgent and necessary.

The methodology utilized in this paper was collected via a systematic and comprehensive desk review of secondary sources. The desk review permits a comparative analysis of the existing literature, primarily qualitative. First, four international

\footnotetext{
${ }^{3}$ For more information about victimology, see: Marchiori, H. (1988) Criminología: la víctima del delito. México: Porrúa. Groenhuijsen M. (2014) 'The development of international policy in relation to victims of crime', International Review of Victimology, 20, pp. 31-48. O'Connell, M. (2008) 'Victimology: A Social Science in Waiting?' International Review of Victimology, 15 (2), pp. 91-104. Cerezo Domínguez, A. I. (2010) The role of victims in the preparation of criminal laws, Seville Andalusian Interuniversity Institute of Criminology.
} 
instruments related to victims of crime, victims power abuse and victims of gross violation of human rights were studied in order to determine the subject of study and, on the other hand, to know victim's rights in the universal system. Second, documents from the Office of the United Nations High Commissioner for Human Rights concerning human rights indicators for measurement and application were reviewed. Finally, some literature concerning human rights research methods was reviewed.

This paper is divided into three parts. With the aim of identifying the subject of study, the first part includes the different notions of the term victim, based on four universal human rights instruments relating to victims: (a) the Declaration of Basic Principles of Justice for Victims of Crime and Abuse of Power; (b) the Declaration on the Protection of All Persons from Enforced Disappearance; (c) the International Convention for the Protection of All Persons against Enforced Disappearances; and (d) the Basic Principles and Guidelines on the Right to a Remedy and Reparation for Victims of Gross Violations of International Human Rights Law and Serious Violations of International Humanitarian Law. The second part uses these instruments to deduce a set of rights to which victims are entitled, on the grounds that these rights reveal the seriousness of the violations, and justify the necessity to rely on the experiences and address the needs of people who have suffered them. The third part shows how victims' testimonies have become primary sources of data and information generation, in addition to being included as one of several indicators to measure compliance with and protection of human rights standards. The latter has made it possible to use the methodology of the social sciences for collecting statements, and systematising and analysing the information collected. This has allowed a multidisciplinary approach to be adopted, albeit not without problems.

\section{UNITED NATIONS STANDARDS RELATING TO VICTIMS. TYPOLOGY}

Although the international community has been concerned with the situation of victims of human rights crimes and violations, at present there is no single, universallyaccepted definition of what a victim is under international law. Each of the universal instruments relating to victims provides a definition and outlines some elements from which the meaning of the term can be derived.

Four instruments have been created that contain universal norms related to victims, which also establish different types of victims. This is in addition to the definition provided by the International Criminal Court which will not be discussed here. ${ }^{4}$ The first of these instruments is the Declaration on Fundamental Principles of Justice for Victims of Crime and Abuse of Power, General Assembly Resolution 40/34, adopted on 29 November $1985 .{ }^{5}$ This Declaration is the first universal norm that places victims at its

\footnotetext{
${ }^{4}$ For more information, see Articles 5, 68, 75 and 79 of the Rome Statute and Rule 85 of the Rules of Procedure and Evidence of the International Criminal Court. See also Olásolo Alonso, H. (2008) 'Cuestiones procesales y procedimentales sobre la posición de las víctimas ante la CPI' in Kai, Both et al. Cuestiones esenciales en la jurisprudencia de la CPI, Granada: Comares, p. 60-70.

5 The Declaration on the Fundamental Principles of Justice for Victims of Crime and Abuse of Power emanated from the discussions of the Seventh United Nations Congress on the Prevention of Crime and the
} 
core, including both victims of crime and victims of abuse of power. The definition provided for victims of crime is as follows:

'Victims' means persons who, individually or collectively, have suffered harm, including physical or mental injury, emotional suffering, economic loss or substantial impairment of their fundamental rights, through acts or omissions that are in violation of criminal laws operative within Member States, including those laws proscribing criminal abuse of power.

This definition includes family members or persons who have an immediate relationship with the direct victim, as well as persons who have suffered harm when intervening to assist or support the victim:

...also includes, where appropriate, the immediate family or dependants of the direct victim and persons who have suffered harm in intervening to assist victims in distress or to prevent victimisation.

The term 'victims of abuse of power' is also defined:

'Victims' means persons who, individually or collectively, have suffered harm, including physical or mental injury, emotional suffering, economic loss or substantial impairment of their fundamental rights, through acts or omissions that do not yet constitute violations of national criminal laws but of internationally recognised rules relating to human rights.

The second instrument is the Declaration on the Protection of All Persons from Enforced Disappearance, adopted by General Assembly Resolution 47/133 of 18 December 1992. The Declaration does not specifically establish the concept of a victim of enforced disappearance, but it indicates that any person who has suffered enforced disappearance (a crime against humanity) will be considered a victim:

... enforced disappearances occur, in the sense that persons are arrested, detained or abducted against their will or otherwise deprived of their liberty by officials of different branches or levels of Government, or by organised groups or private individuals acting on behalf of, or with the support, direct or indirect, consent or acquiescence of the Government, followed by a refusal to disclose the fate or whereabouts of the persons concerned or a refusal to acknowledge the deprivation of their liberty, which places such persons outside the protection of the law.

The third instrument related to victims is the International Convention for the Protection of All Persons from Enforced Disappearances, of 20 December, 2006 (the

Treatment of Offenders, held in Milan, Italy, on 26 August to September 6, 1985. On 29 November of the same year, the General Assembly approved the text recommended by the Congress at the same time as it approved Resolution 40/34. 
Convention). Article 24.1 of the Convention describes the concept of victim of enforced disappearance as being:

...the disappeared person and any individual who has suffered harm as the direct result of an enforced disappearance.

The Convention contemplates two types of direct victims, on the one hand, the disappeared person and, on the other, any individual who has suffered direct harm as a result of an enforced disappearance.

The fourth instrument is the Basic Principles and Guidelines on the Right to a Remedy and Reparation for Victims of Gross Violations of International human rights law and Serious Violations of International humanitarian law, adopted by Resolution 2005/35 of the Human Rights Commission of United Nations, on 19 April, 2005. It mentions both victims of human rights violations and victims of serious violations of international humanitarian law. It also distinguishes between two types of victims, direct and indirect. Direct victims are:

...persons who individually or collectively suffered harm, including physical or mental injury, emotional suffering, economic loss or substantial impairment of their fundamental rights, through acts or omissions that constitute gross violations of International Human Rights Law, or serious violations of International humanitarian law.

While indirect victims are described in the following terms:

... Where appropriate, and in accordance with domestic law, the term 'victim' also includes the immediate family or dependants of the direct victim and persons who have suffered harm in intervening to assist victims in distress or to prevent victimisation.

In light of the above instruments, there are several types of victims, namely victims of crimes, victims of abuse of power, victims of gross violations of international human rights standards and victims of serious breaches of international humanitarian law. This group includes the characteristics of the term 'victim', that is, persons who directly or indirectly (family members or people who have suffered harm when helping a victim) have faced an unlawful act (offence, crime, violation of an international obligation) either individually or collectively by the action or omission of states; or of an individual or groups of individuals. This definition cannot be interpreted to include legal persons in any manner or at any time (Burgorgue-Larsen, 2003, p. 14).

\section{VICTIMS' RIGHTS WITHIN THE UNIVERSAL SYSTEM}

The four universal instruments mentioned in the previous section list a catalogue of rights held by the victims, which include: 
a) Right of access to justice and fair treatment (including the right to recourse to expeditious and effective judicial process). Victims' right of access to administrative and other bodies, as well as to mechanisms, measures and procedures used in accordance with domestic law.

b) The right to know the truth about the circumstances of enforced disappearance and the fate of the disappeared person, as well as respect for the right to freedom to seek, receive and disseminate information to this end.

c) The right to create and freely participate in organisations and associations with the purpose of helping to establish the circumstances of forced disappearances and the fate of disappeared persons.

d) The right of victims of enforced disappearance to assistance.

e) The right to prompt, fair and effective remedies, including reparation.

The right to reparation is closely related to the rights to justice and truth. These rights have generated a growing debate in the international community, which has led to the production of soft law instruments. These complement the regulations derived from hard law, since they propose guidelines and offer a range of measures to manage these rights. In addition to the four instruments mentioned above, there is another important document relating to the rights of the victims, namely, the Updated Set of principles for the protection and promotion of human rights through action to combat impunity, approved by the Commission on Human Rights in February 2005. ${ }^{6}$ This instrument, together with the Basic Principles and Guidelines on the Right to a Remedy and Reparation for Victims of Gross Violations of International human rights law and Serious Violations of International humanitarian law (the Basic Principles and Guidelines on the Right of Victims of Violations), contribute to the implementation of measures of truth, justice and reparation in contexts where serious human rights violations are widespread. In this way, they supplement those binding instruments from which obligations for the state are derived. They also provide different modes of jurisprudence.

The Updated Set of principles for the protection and promotion of human rights through action to combat impunity is the 'most up-to-date and specific international human rights law instrument that recognises the rights of victims to the truth, and to access to justice and reparation' (Beristain, C. and González E., 2012, p. 253). The Basic Principles and Guidelines on the Right of Victims of Violations indicate that when states' actions or omissions generate violations of human rights and international humanitarian law, states are obliged to investigate, prosecute and punish those responsible for the violations, and to generating the right to reparation for the victims. Point 15 of this document establishes the following:

\footnotetext{
${ }^{6}$ Economic and Social Council. Updated Set of principles for the protection and promotion of human rights through the fight against impunity. E/CN.4/2005/102/Add.1. 8 February 2005.
} 
Adequate, effective and prompt reparation is intended to promote justice by redressing gross violations of international human rights law or serious violations of international humanitarian law. Reparation should be proportional to the gravity of the violations and the harm suffered.

The document establishes five dimensions of reparation, which have been enacted through jurisprudence, listed in paragraphs 19-23 of the Basic Principles and Guidelines on the Right of Victims of Violations:

- Restitution involves restoring the victim to the original situation before the violations of International human rights law or serious violations of International humanitarian law occurred. For instance, the restoration of liberty, enjoyment of human rights, identity, family life and citizenship, the return to one's place of residence, restoration of employment and return of property.

- Compensation refers to the monetary compensation that should be appropriate and proportional to the seriousness of the violation and the circumstances of each case. The following needs to be taken into account: physical or mental harm; lost opportunities, including employment, education and social benefits; material damages and loss of earnings, including loss of earning potential; moral damage; costs required for legal or expert assistance, medicine and medical services, and psychological and social services.

- Rehabilitation includes medical and psychological care, as well as legal and social services.

- Satisfaction refers to effective measures aimed at the cessation of continuing violations; the verification of the facts and full and public disclosure of the truth to the extent that such disclosure does not cause further harm or threaten the safety and interests of the victim, the victim's relatives, witnesses, or persons who have intervened to assist the victim or prevent the occurrence of further violations; the search for the whereabouts of the disappeared, for the identities of the children abducted, and for the bodies of those killed, and assistance in the recovery, identification and reburial of the bodies in accordance with the expressed or presumed wish of the victims, or the cultural practices of the families and communities; an official declaration or a judicial decision restoring the dignity, the reputation and the rights of the victim and of persons closely connected with the victim; public apology, including acknowledgement of the facts and acceptance of responsibility; and judicial and administrative sanctions against persons liable for the violations, among others.

- The guarantees of non-repetition include: ensuring the effective civilian control of military and security forces; the guarantee that all civil and military proceedings abide by international standards of due process, fairness and impartiality; the strengthening of the independence of the judiciary; the protection of the persons in the legal, medical and health-care professions, the media and other related professions, and human rights defenders; the promotion of the observance of codes of conduct and ethical standards, in particular international standards, by public officials, among others. 
The effectiveness of these measures will be as much in their coherence as in their internal integrity. None of them substitutes another; they are all interrelated and must be integral to the whole. The International Center for Transitional Justice mentions both internal integrity (coherence between the requirements and the ways of carrying out reparations) and external integrity, (relationship between the measures and the justice policies and institutional or criminal reforms). ${ }^{7}$ In this sense, the measures must be a set of actions designed to mitigate the damage caused to victims of human rights violations and to restore their rights. The coherence and integrity of the measures must be reflected in a public policy aimed at changing the political and social situation in which the violation of human rights was committed.

The measures must have legitimacy vis-à-vis the victims in order to be satisfactory and effective. This requires the victims' participation in the entire process. As the InterAmerican Commission pointed out:

... the participation of the victims in the different procedural stages constitutes a guarantee of the right to truth and justice, and is part of the complex structure of checks and balances of the criminal process, and fosters the citizen's control of the acts of the State (Inter-American Court of Human Rights Commission, 2009, para. 67).

The visibility of the victims in the different instruments has resulted in a shift from victims being passive and marginalised in regard to the process of investigating the criminal act to them becoming active subjects. Some authors have noted that the participation of the victims 'illuminates the guilt and facilitates a fair trial' (Abreu, 2017, p. 101). This is important, especially because in the case of serious crimes (such as forced disappearance, torture, kidnapping), it is not only the persons who suffer these violations that have their life disrupted; a state's democratic principles and the Rule of Law also become strongly disturbed.

The two previous sections have outlined who the victims are, as well as their rights. The following section contains an explanation of why it is important to take into account the participation of the victims through their testimonies. They not only contribute to the ethical-political legitimacy of the investigation, but also to the establishment of standards and their effective implementation, as well as to the formulation, application and effectiveness of public policies on human rights.

Testimonies are important as they are a direct source of information on social facts that can complement the information obtained through secondary and tertiary sources. In addition, they confer a central role to those persons or groups who have had their rights violated, turning them into active subjects in the development, implementation and evaluation of public policies related to the rights of justice, truth and reparation.

\footnotetext{
${ }^{7}$ For more information, see: International Center of Transitional Justice-APRODEH (2002). Parámetros para el diseño de un programa de reparaciones en el Perú. Lima: ICTJ,
} 


\section{GENERATION OF DATA AND INFORMATION BASED ON THE VICTIMS' TESTIMONIES}

Ever since the 1980s, the testimonies of victims of serious violations of human rights, infractions of international humanitarian law, and crimes against humanity have played an increasingly major part in generating data and collecting information. They have been used as primary sources in the truth commissions that have been implemented in the last forty years. For instance, five thousand one hundred eighty testimonies were collected in Guatemala's REMHI project, which were included in the Guatemala Nunca Más report (1995-1998). Another example was the Peru's Truth and Reconciliation Commission, which collected nearly seventeen thousand testimonies about the violence, including harrowing stories of massacres, disappearances, torture, and sexual abuse.

.... detailed and accurate record of the acts of violence, the conditions in which they occurred, the actors directly involved and the consequences of those acts... (CVR, 2003, pp. 32-33).

In accordance with the Guide for Human Rights Indicators for Measurement and Application, prepared in 2012 by the Office of the United Nations High Commissioner for Human Rights, testimonies (one of the sources and mechanisms for generating data) are used in States parties' reports as an indicator to assess international human rights monitoring mechanisms such as United Nations Treaty Bodies, the reports by special rapporteurs, the universal periodic review by the Human Rights Council, and in the recommendations of its bodies to states. For instance, special rapporteurs carry out country visits to assess the situation of human rights at the national level. During such missions, the experts assess the general human rights situation in a given country and they meet with national and local authorities, with members of non-governmental organizations, civil society organizations and victims of human rights violations. One of their principal activities is to get direct information from victims of human rights violations (testimonies). Country visits' findings, conclusions and recommendations by special procedures are published in mission reports to the Human Rights Council.

In August 2016, a rapport was published jointly by United Nations Assistance Mission for Iraq (UNAMI) and OHCHR under their respective mandates. The information contained in this report is based on accounts obtained directly from survivors and witnesses of abuses of international human rights law and/or serious violations of international humanitarian law gathered by UNAMI human rights investigators since the attack on Sinjar in August 2014. ${ }^{8}$

The demand for (quantitative and qualitative) indicators is present in the normative framework of human rights. For instance, quantitative indicators are mentioned in some of the treaties; in the International Covenant on Economic, Social and Cultural Rights (Article 16); in the International Covenant on Civil and Political Rights (Article 40); and in the Convention on the Rights of Persons with Disabilities (Article 31):

\footnotetext{
${ }^{8}$ https://www.ohchr.org/Documents/Countries/IQ/UNAMIReport12Aug2016 en.pdf.
} 
States Parties undertake to collect appropriate information, including statistical and research data, to enable them to formulate and implement policies to give effect to the present Convention. The process of collecting and maintaining this information shall comply with internationally accepted norms to protect human rights and fundamental freedoms and ethical principles in the collection and use of statistics.

The use of quantitative or qualitative indicators based on facts or judgments in human rights evaluations provides complementary and mutually supportive options. These indicators are instruments for obtaining an approximate idea of the actual circumstances; their level of accuracy is optimal provided that there is a high standard both in terms of the information and the methodologies used to collect, systematise and analyse this information. It is important to encourage the use of factual and quantitative indicators to better inform these assessments (OHCHR, 2012, p. 28).

These indicators include events-based data as one of the four categories of the data generation mechanism (see Figure 1). In view of this, the OHCHR points out two considerations. On the one hand, the sources and identified data-generating mechanisms should be suitable for assessing the compliance of State parties with international human rights treaties. As a result, the focus should be on indicators that are fact-based or use objective methods of data collection and presentation. And on the other hand, they should combine different sources and data-generating mechanisms to encourage a more comprehensive and credible assessment of any human rights situation (OHCHR, 2012, p. $51)$.

\section{Figure 1}

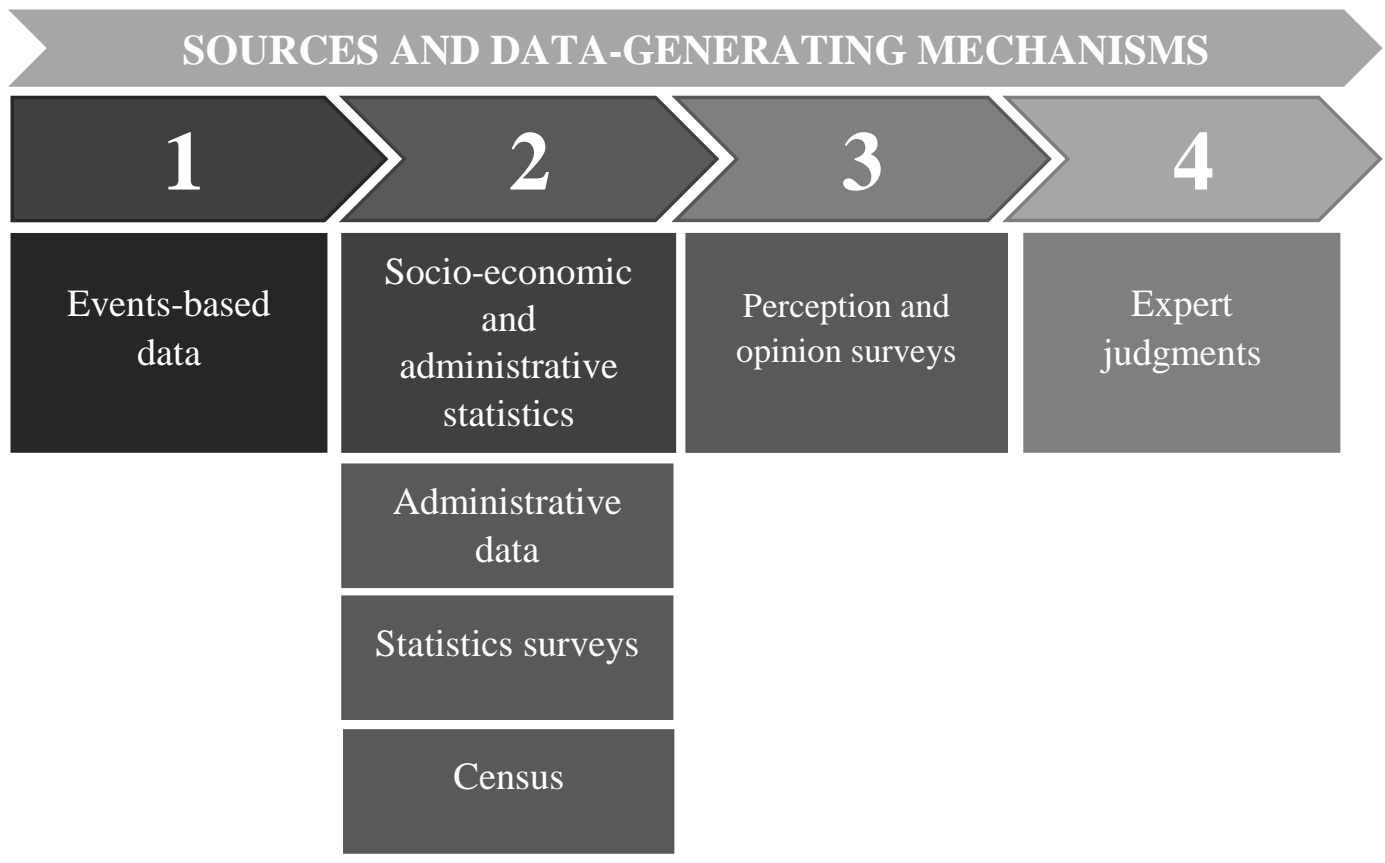

Source: OHCHR, 2012, p. 52. 
Events-based data refer to qualitative or quantitative data that can be linked to events characterised by human rights violations and infractions of international humanitarian law or crimes against humanity. The information collected describes acts and identifies the victims and the perpetrators.

According to the OHCHR, events-based data are obtained from testimonies of victims or witnesses; information provided by the media and reports of states, civil society organisations, national human rights institutions, and international human rights monitoring mechanisms. However, due to the importance and participation of the victims in the investigation processes through non-governmental organisations, organisations created by them and academic research, their testimonies have started to have a place in the sources and data-generating mechanisms.

This section will only take into account the collection of data from testimonies in order to maintain the focus of the article (victims' testimonies as primary sources), without underestimating the importance of the other elements.

\subsection{Events-based data: collection of testimonies}

Collecting testimonies is an area of fieldwork that uses methodology from the social sciences, applying semi-structured in-depth interviews to individuals or using focus groups. It is not the aim of this section to provide detailed information on how to carry out these activities, as there is substantial literature on the subject. ${ }^{9}$ However, it is interesting to mention some aspects that should be basic requirements for the collection of this kind of data that can be conducive to the search for justice, truth and reparation. Aspects identified by specialists during the last two decades include:

(a) The central role of the victims. The fundamental element in investigations on human rights violations is that the victims are at the heart of the process through their testimonies. This involves learning to listen and take into account their experiences, information and expectations in the investigation process; facilitating spaces for effective dialogue; maintaining consistent behaviour; and establishing satisfactory communication and support mechanisms (Beristain, et al, 2018). This perspective is what is known as the psychosocial approach. An approach that focuses on understanding the impacts of violations at the personal, family or collective level, considering the victims' ways of coping or resistance, as well as their perceptions, expectations and claims regarding the facts, in contrast with those of perpetrators and of the state.

... the status of victim requires providing a place, a space and a time for victims to speak for themselves; it means having them narrate their stories over and over again, in an attempt to investigate the meaning of their

\footnotetext{
${ }^{9}$ Bryman, A. (2016). Social Research Methods, $5^{\text {th }}$ ed. Oxford: Oxford University Press. Della Porta D. and Keating, M. (eds.) (2008) Approaches and Methodologies in Social Sciences: A pluralist Approach. Cambridge: Cambridge University Press. Kvale, S. and Brinkmann, S. (2009) Interviews: Learning the craft of qualitative research interviewing, $2^{\text {nd }}$ ed. London: Sage Publications.
} 
experience and follow it through to its conclusion, thus learning to look at the world from the perspective of the one's solitude self ... the mystery hidden behind the victim's testimony (Bárcena and Mélich, 2003, pp. 198-203).

(b) Visits to the sites or places where the victims are located. During the fieldwork, it is necessary to visit the places where the victims and witnesses are. Different activities may be undertaken: having individual interviews with other people (witnesses), working with focus groups to reconstruct the events, and meeting family members, among others. Sometimes it is necessary to re-interview and check data and local or regional information that can only be obtained first-hand (Beristain et al, 2018), as well as understanding the social, political and cultural context in which violations of human rights were carried out.

(c) Information regarding human right violations. Each statement must include the account that provides information regarding the violation of human rights in question: What happened, when and where? Who were the perpetrators? What effects did this have on their life (physical, psychological, economic, and social, etc.)? How did the victim deal with that situation? Why did it happen, or how can it be accounted for? What should be done to avoid this situation and whose responsibility is it? According to Rodríguez Maeso, this involves the interrelation and complementary nature of legal truth and historical truth and, therefore, of legal knowledge and socio-historical knowledge (Rodríguez Maeso, 2011). In other words, it is a construction of the facts relying on different of social science disciplines, including history and law.

(d) Empowerment of people during the research process. During the process of generating data and information, and during the entire stage of action research, one of the cross-cutting objectives must be to empower the people (victims, defenders, etc.), who participate in the project or study (Beltrán, 2015, p. 8). In this way, a voice is given to people who may never have had the opportunity to talk about these facts in a process which involves seeking truth, justice and reparation.

(e) Network construction. It is advisable to work in partnership with local organisations and other actors involved in the subject under investigation. During the process, strategies must be designed to share knowledge, techniques and abilities regarding awareness of international human rights norms, research capabilities, skills to engage in interaction with other (state and non-state) actors, and mobilisation of media or society. In other words, networking strategies. Research is a continuous process of seeking changes in the lives of people whose rights are at risk in support of the whole society (Beltrán, 2015, p. 8).

(f) Multidisciplinary analysis. The information that comes from testimonies is systematically recorded, by using definitions and common classifications based on the normative human rights framework that allow the pertinent data to be compiled and consolidated. Quantitative data needs to be obtained in connection with the number of victims, their age, their sex, their profession; qualitative data must also 
be collected concerning the socio-political context (local, regional or national), and the physical, psychological or social consequences for those who suffered violations (from a gender perspective), as well as types of categories of human rights crimes or violations. These include arbitrary execution, arbitrary detention, forced disappearance, forced displacement, torture, robbery, etc. (OHCHR, 2012, p. 14). The professionals from each of the specialties reconstruct and interpret the facts from the point of view of the different disciplines within the social sciences: anthropology, sociology, geography, history, law, political science, economics, communication, pedagogy and psychology; and even medicine. However, at this point there is a discussion between jurists and professionals of other disciplines: the former argue that the analysis is and should be constrained to the legal field. This is because human rights have been developed and recognised by international law, which in turn has illuminated the internal legal system of States. ${ }^{10}$

In all these cases, the CVR resorted to experts at the cutting edge of scientific and technical methods in order to ensure as much objectivity as possible: criminological reports, judicial expertise, forensic anthropology, laboratory analysis, etc. (CVR, 2003, p. 33).

The objective of research on human rights violations should be twofold: on the one hand, to contribute to the implementation of effective policies on truth, justice and reparation that effectively ensure the recovery of the victim and, where possible, restore the victim to their previous situation; and, on the other hand, to contribute to the transformation of political systems that allow such actions or omissions. This is done by using tools from the social sciences because this science has a long tradition in analysis the conditions under human beings live.

Since the late nineties, the social sciences has addressed human rights and has generated knowledge about the human condition relevant to rights-based research, while at the same time has made progress in developing methods that are applicable in the field of human rights. Moreover, the social sciences have problematized human rights in ways that have challenged the predominance of law and opened up new avenues of inquiry that provide greater insight into the fundamental challenges that need to be overcome for a truly global implementation of human rights norms (Landman, 2010, p. 19). This last argument explains next figure.

\footnotetext{
${ }^{10}$ For more information on this debate, see: Wilson, R. A. (1997) 'Representing Human Rights Violations: Social Contexts and Subjectivities' in Wilson. R. (Ed.), Human Rights, Culture and Context. Anthropological Perspectives. London: Pluto Press, p. 134-160. Ross, F. C. (2003) 'Using rights to measure wrongs. A case study of method and moral in the work of the South African Truth Commission' in Wilson, R. A. and Mitchell, J. P. Human Rights in Global Perspective. Anthropological studies of rights, claims and entitlements. London: Routledge (ASA Monographs, V. 40), p. 163-182. Hastrup, K. (2003) 'Representing the common good. The limits of legal language' in Wilson R.A. and Mitchell, J.P. Human Rights in Global Perspective. Anthropological studies of rights, claims and entitlements. London: Routledge, pp. 16-32.
} 
Figure 2

\begin{tabular}{|c|c|}
\hline \multicolumn{2}{|c|}{ THE IMPORTANCE OF THE VICTIMS' TESTIMONIES } \\
\hline For victims and their families & Documenting the case / institutions / society \\
\hline Compiling their experiences. & $\begin{array}{l}\text { Incorporating the impacts on and } \\
\text { consequences for, the victims. }\end{array}$ \\
\hline Empowering and maintain their dignity. & $\begin{array}{l}\text { Recognising them as victims and } \\
\text { acknowledging their rights. }\end{array}$ \\
\hline $\begin{array}{l}\text { Providing a social framework for recognising } \\
\text { their experience. }\end{array}$ & $\begin{array}{l}\text { Generating empathy for the victims' } \\
\text { experience. }\end{array}$ \\
\hline $\begin{array}{l}\text { Validating their experience as a source of } \\
\text { information in investigations. }\end{array}$ & $\begin{array}{l}\text { Preparing recommendations on the right to } \\
\text { truth, justice and reparation that contribute to } \\
\text { the implementation of appropriate public } \\
\text { policies. }\end{array}$ \\
\hline
\end{tabular}

Sources: BERISTAIN et al., 2018, p. 20; OHCHR, 2012.

This subject area, which seeks to be multidisciplinary, has some critical currents, like any research methodology. For example, Ball and Spirer reported repeated criticism of the collection of data and information by way of testimonies from victims of human rights violations (Ball and Spirer, 2000, pp.1-2):

(a) The structuring of data on human rights is a complex process, and countless errors may be made in the data that yield statistics that can distort the truth. In addition to the usual errors that affect statistical work (reliability of data processors and researchers, interview bias, numerical and typographical errors, etc.), the atrocious errors result from oversimplification. For example, when a person suffers multiple violations in a given event, but only the most serious one is reported, in order to avoid simplification and find a balanced view, there should be an open debate among the different specialists in the team, and close attention needs to be paid to the preparation of the database.

(b) The persons chosen to be interviewed are not representative of the group of victims. Therefore, the data can be biased, reflecting only the knowledge of the people interviewed. In this context, 'bias' means a distortion of historical reality.

(c) The systematisation of the data and information collected from testimonies is not an easy task, especially if such information is intended to be analysed and studied by various specialties of the social or medical sciences. The complexity of the information management system and, in particular, of the database, reflects the complexity of the narratives and of the legal and scientific concepts necessary to serve the cause of truth (Ball and Spirer, 2000, p. 2). To achieve accuracy and consistency, the information management system should standardise the classification and categorisation of information. For instance, it should standardise the existing definitions of torture, 
enforced disappearance, etc. as established in international instruments, or establish criteria on how to detail places, facts, etc. A careful and accurate classification is necessary to ensure that high-quality data is obtained. The whole system must have a high standard to be credible and valid.

(d) A similarly important issue is the collection, processing and dissemination of any statistical information, as it has repercussions on the right to information, the right to privacy, and the protection and confidentiality of data, which requires compliance with the legal and institutional norms related to ethics, statistics and human rights. This problem has sometimes been resolved by sending the data to a different State from that where the research was carried out and in human rights research centres. The OHCHR has suggested adopting or applying ethical safeguards such as the Fundamental Principles of Official Statistics and the Declaration of Professional Ethics of the International Statistical Institute, with a view to creating an institutional framework to help prevent the misuse of data in the future.

\section{CONClusions}

1. The United Nations is paid little attention to victims and, in general, to their situation in the face of human rights violations. However, as a result of serious armed conflicts, many of them ethnic, as well as wars of independence, dictatorships, etc. in the mid-twentieth century, the international community became more interested in the victims' situation and began the production of international instruments such as: (a) the Declaration of Basic Principles of Justice for Victims of Crime and Abuse of Power; (b) the Declaration on the Protection of All Persons from Enforced Disappearance; (c) the International Convention for the Protection of All Persons from Enforced Disappearance; and d) the Basic Principles and Guidelines on the Right to a Remedy and Reparation for Victims of Gross Violations of International human rights law and Serious Violations of International humanitarian law. The objectives of these mechanisms are, on the one hand, to provide elements to define who the victims of violations of human rights and humanitarian law are and, on the other, to establish a catalogue of victims' rights, namely the right to access to justice and fair treatment, the right to know the truth, the right to create and freely participate in organisations and associations to help them restore the situation in which they were living before suffering the violations, and the right to reparation and remedies, in an expeditious, fair and effective manner.

2. The production of international instruments related to victims and their rights, the emergence of victimology, and the demands of victims on questions of justice, truth, compensation and reparation for victims, due to the psychological, physical, social, and political consequences (among others) faced by them have caused victims to be taken into account through their testimonies. These have been considered as one of the sources of data and information generation, especially by the truth commissions that emerged in the 1980s and, gradually, have been included in the reports of the different United Nations agencies. 
3. In the document Human rights indicators: A Guide to Measurement and Implementation, by the Office of the United Nations High Commissioner for Human Rights, victims' testimonies were identified as one of the data sources and generation mechanisms, and as one of the indicators to measure the application of and compliance with human rights, among them, the rights to justice, truth and reparation. Thus, testimonies are used as part of the indicators in States parties' reports to international human rights monitoring mechanisms such as United Nations Treaty agencies, the reports of special rapporteurs, the periodic universal review carried out by the Human Rights Council; and the recommendations to the States parties for preparing reports by the working groups of its different bodies.

4. The compilation of testimonies is an area of fieldwork that employs methodology from the social sciences, applying semi-structured in-depth interviews to individuals or using focus groups. Over the last two decades, various specialists in the subject have noted various aspects for improving the results achieved by this methodology, notably including: (a) the importance of placing the victims at the heart of the investigations or processes in the search for the truth; (b) visits to the sites where the events took place; (c) obtaining information related to the violation of human rights that answers the following questions: What happened, when and where? Who were responsible? What effects did this have on your life? Physical, psychological, economic, social, etc. How did you deal with that situation? Why did it happen? How can it be accounted for? What should be done to avoid this situation and whose responsibility is it to ensure this? (d) Empowerment of the victims during the investigation process; (e) networking and, (f) multidisciplinary analysis of the data and information collected.

However, this methodology has received considerable criticism, including the following points: (a) the structuring of data on human rights is a complex process and there are countless possible errors in the data that yield statistics that can distort the truth; (b) the persons chosen to be interviewed are not representative of the group of victims; (c) the systematisation of the data and information gathered from testimonies is not an easy task, especially if such information is intended to be analysed and studied by various disciplines of the social sciences or medical sciences; and, (d) the collection, treatment and dissemination of any statistical information has repercussions on the right to information, the right to privacy, and the protection and confidentiality of data, which requires compliance with legal and institutional norms related to ethics, statistics and human rights. 


\section{REFERENCES}

ABREU and ABREU, J. C. (2009) 'La Victimología la luz de los Derechos Humanos', Prolegómenos. Derechos y Valores, XII (23), p. 99-111. https://doi.org/10.18359/prole.2498

BALL, P. and SPIRER, H. F. (2000) Making the Case. Investigating Large Scale Human Rights Violations Using Information Systems and Data Analysis. Washington, DC, USA: American Association for the Advancement of Science (AAAS) Science and Human Rights Program.

BÁRCENA, F. and MÉLICH, J. C. (2003) 'La mirada excéntrica. Una educación desde la mirada de la víctimas' in Mardones, J. M. and Reyes Mate, R. (Eds.) La ética ante las víctimas. Barcelona: Anthropos.

BELTRAN VERDES, E. (2015) Investigación de Violaciones de Derechos Humanos y Crímenes de Derecho Internacional [online]. Available at:http://www.derechoshumanos.unlp.edu.ar/assets/files/T\%C3\%A9cnicas\%20d e\%20Investigaci\%C3\%B3n..pdf (Accessed: 30 May 2019).

BERISTAIN, C. and GONZÁLEZ HIDALGO, E. (2012) El oasis de la memoria, vol. II. Bilbao: Hegoa.

BERISTAIN, C. et al. (2018) Metodologías de investigación, búsqueda y atención a las víctimas. Del caso Ayotzinapa a nuevos mecanismos en la lucha contra la impunidad. Colombia: Editorial Temis. https://doi.org/10.2307/j.ctt21kk17r

BURGORGUE-LARSEN, L. (2003) 'Las víctimas del delito en el proceso penal internacional: el ejemplo de la corte penal internacional' [online]. Available at: https://revistas.uam.es/revistajuridica/article/download/6159/6615 (Accessed: 30 May 2019).

CEREZO DOMÍNGUEZ, A. I. (2010) El protagonismo de las víctimas en la elaboración de las leyes penales. Sevilla: Instituto Andaluz Interuniversitario de Criminología.

COMISIÓN DE LA VERDAD Y LA RECONCILIACIÓN (2003) Informe Final [online]. Available at: www.cverdad.org.pe (Accessed: 30 May 2019).

COMISIÓN INTERAMERICANA DE DERECHOS HUMANOS (2009) Informe sobre seguridad ciudadana $y$ derechos humanos [online]. Available at: https://www.oas.org/es/cidh/docs/pdfs/seguridad\%20ciudadana\%202009\%20esp .pdf (Accessed: 30 May 2019).

CRUZ, LUIS M. (2010) 'El derecho de reparación a las víctimas en el Derecho Internacional. Un estudio comparativo entre el derecho internacional de responsabilidad estatal y los principios básicos de reparación de víctimas de derechos humanos', Revista de Derecho Político, no. 77, p. 185-209. https://doi.org/10.5944/rdp.77.2010.9108

DE CASADEVANTE ROMANÍ, C. (2009) 'Las Víctimas y el Derecho Internacional', A.E.D.I., vol. XXV, p. 3-66. 
DÍAZ COLORADO, F. (2006) 'Una mirada desde las víctimas: el surgimiento de la Victimología. Ensayo’, Umbral Científico, no. 9, p. 141-159.

DRAPIN, I. (1974), 'El derecho de las víctimas', Anuario de Derecho Penal y Ciencias Penales [online]. Available at: http://blog.uclm.es/cienciaspenales/files/2016/11/1999_fasc_I_Parte1.pdf (Accessed: 30 May 2019).

ECONOMIC AND SOCIAL COUNCIL Updated Set of principles for the protection and promotion of human rights through the fight against impunity. E/CN.4/2005/102/Add.1. 8 February 2005 [online]. Available at: https://www.ohchr.org/EN/Issues/TruthJusticeReparation/Pages/InternationalIns truments.aspx (Accessed: 30 May 2019).

HUMAN RIGHTS COMMISSION OF UNITED NATIONS Principles and Guidelines on the Right to a Remedy and Reparation for Victims of Gross Violations of International Human Rights Law and Serious Violations of International Humanitarian Law. Resolution 2005/35. 19 April 2005 [online]. Available at: https://www.ohchr.org/EN/Issues/TruthJusticeReparation/Pages/InternationalIns truments.aspx (Accessed: 30 May 2019).

INTERNATIONAL CENTER OF TRANSITIONAL JUSTICE-APRODEH (2002) Parámetros para el diseño de un programa de reparaciones en el Perú. Lima: ICTJ.

LANDMAN, T. (2010) "Social science methods and human rights" in Coomans, F. et al Methods of human rights research. Maastricht: Intersentia, pp. 19-44.

MARCHIORI, H. (2016) 'Los Derechos de las Vícitmas’, Víctimología, Serie 18, p. 159170.

OFFICE OF THE UNITED NATIONS HIGH COMMISSIONER FOR HUMAN RIGHTS (2012). Guide for Human Rights Indicators for Measurement and Application. Geneva [online]. Available at: https://www.ohchr.org/EN/Issues/TruthJusticeReparation/Pages/InternationalIns truments.aspx (Accessed: 30 May 2019).

OFFICE OF THE UNITED NATIONS HIGH COMMISSIONER FOR HUMAN RIGHTS A Call for Accountability and Protection: Yezidi Survivors of Atrocities Committed by ISIL. August 2016 [online]. Available at: https://www.ohchr.org/Documents/Countries/IQ/UNAMIReport12Aug2016_en. pdf (Accessed: 30 October 2019).

RODRÍGUEZ MAESO, S. (2011) 'Testimonios, discurso experto y comisiones de la verdad: el contexto de la denuncia', Política y Sociedad, 48 (3), p. 587-602. https://doi.org/10.5209/rev_POSO.2011.v48.n3.36422

SANZ HERMIDA, A. MA. (2009) Víctimas de delitos: derechos, protección y asistencia. Madrid: Iustel. 
SMITH, S. and MCCONNELL, L. (2018) 'Introduction to human rights research methods' in Smith, S. and McConnell, L. Research methods in human rights. New York: Routledge. https://doi.org/10.4324/9781315672632

UNITED NATIONS GENERAL ASSEMBLY Convention on the Rights of Persons with Disabilities, 13 December 2006 [online]. Available at: https://www.ohchr.org/Documents/HRBodies/CRPD/A.68.55-ENG.doc (Accessed: 30 May 2019).

UNITED NATIONS GENERAL ASSEMBLY Declaration of Basic Principles of Justice for Victims of Crime and Abuse of Power. Resolution 40/34, 29 November 1985 [online]. Available at:

https://www.un.org/en/genocideprevention/documents/atrocitycrimes/Doc.29_declaration\%20victims\%20crime\%20and\%20abuse\%20of\%20p ower.pdf (Accessed: 30 May 2019).

UNITED NATIONS GENERAL ASSEMBLY Declaration on the Protection of All Persons from Enforced Disappearance. Resolution 47/133, 18 December 1992 [online]. Available at:

https://www.ohchr.org/en/professionalinterest/pages/enforceddisappearance.aspx (Accessed: 30 May 2019).

UNITED NATIONS GENERAL ASSEMBLY International Convention for the Protection of All Persons against Enforced Disappearances. Resolution 47/133, 20 December 2006 [online]. Available at: https://www.ohchr.org/en/hrbodies/ced/pages/conventionced.aspx (Accessed: 30 May 2019).

UNITED NATIONS GENERAL ASSEMBLY International Covenant on Civil and Political Rights. Resolution 2200A (XXI), 16 December 1966 [online]. Available at: https://www.ohchr.org/en/professionalinterest/pages/ccpr.aspx (Accessed: 30 May 2019).

UNITED NATIONS GENERAL ASSEMBLY International Covenant on Economic, Social and Cultural Rights. Resolution 2200A (XXI), 16 December 1966 [online]. Available at: https://www.ohchr.org/EN/ProfessionalInterest/Pages/CESCR.aspx (Accessed: 30 May 2019).

Received: June $20^{\text {th }} 2019$

Accepted: October $4^{\text {th }} 2019$ 